\title{
6.5 Сучасні аспекти діяльності бюро кредитних історій в Україні
}

Бюро кредитних історій розпочинають свою діяльність 3 моменту отримання ліцензії, яку надає НБУ відповідно до Ліцензійних умов на підставі заяви бюро і документів за умови відповідності бюро кредитних історій організаційним, технологічним та кваліфікаційним вимогам.

В Україні отримали ліцензії і здійснюють профільну діяльність вісім бюро кредитних історій [294]:

- ПрАТ «ПЕРШЕ ВСЕУКРАЇНСЬКЕ БЮРО КРЕДИТНИХ ІСТОРІЙ»;

- П ПрАТ «МГЖНАРОДНЕ БЮРО КРЕДИТНИХ ІСТОРІЙ»;

- ТЗОВ «УКРАЇНСЬКЕ БЮРО КРЕДИТНИХ ІСТОРІЙ»;

- ТзОВ «УНІВЕРСАЛЬНЕ БЮРО КРЕДИТНИХ ІСТОРІЙ»;

- ТЗОВ «НЕЗАЛЕЖНЕ БЮРО КРЕДИТНИХ ІСТОРІЙ»;

- ТзОВ «БЮРО КРЕДИТНИХ ІСТОРІЙ «УКРАЇНСЬКЕ КРЕДИТНЕ БЮРО»;

- ТзОВ «РОЗДРІБНЕ БЮРО КРЕДИТНИХ ІСТОРІЙ»;

- ТзОВ «ОНЛАЙН БЮРО КРЕДИТНИХ ІСТОРІЙ».

Однак, варто зазначити, що хоча в Сдиному реєстрі бюро кредитних історій, станом на 01.01.2021 р. зареєстровано вісім бюро, значною базою даних володіють чотири бюро: Українське бюро кредитних історій; Міжнародне бюро кредитних історій; Перше Всеукраїнське бюро кредитних історій; Бюро кредитних історій «Українське кредитне бюро», і 85\% банків зазвичай користуються послугами двох або трьох приватних кредитних бюро, що свідчить про незрілість ринку. Водночас банки більше довіряють приватним кредитним бюро з незалежним акціонерним капіталом.

Усі функціонуючі бюро кредитних історій володіють певним сегментом інформації, а тому в Україні єдиної бази кредитних історій, з якою банкам було б зручно працювати, не існує (частково формування такої бази здійснюється на рівні держави через Кредитний реєстр НБУ). Особливістю діяльності кредитних бюро в Україні є те, що на 97\% бази даних вони формують за рахунок надходження 
інформації із банків. Коефіцієнт ефективності пошуку становить близько $61 \%$ у кожного з трьох найбільших приватних кредитних бюро. За суміщення їх роботи рівень ефективності підвищується до 85\%, і якщо три бюро працюють одночасно, це дає практично повне покриття ринку. При цьому, кожне кредитне бюро має власні тарифи, що відрізняються в залежності від типу та кількості звітів.

За кількістю партнерів лідером серед бюро кредитних історій в Україні є Українське бюро кредитних історій - бюро налічує 4031 партнерів [295]. Друге місце займає Перше Всеукраїнське бюро кредитних історій, партнерами якого є 82 банки, 196 фінансових компаній та 90 кредитних спілок [296].

Українське бюро кредитних історій є також лідером щодо бази кредитних історій, в арсеналі якого 90,8 млн кредитних історій та більше 435,1 млн запитів до бюро [295] (табл.6.5.1).

Таблиця 6.5.1.

Основні показники діяльності бюро кредитних історій України

\begin{tabular}{|l|l|l|l|}
\hline $\begin{array}{l}\text { Назва бюро } \\
\text { кредитних історій }\end{array}$ & $\begin{array}{l}\text { Кількість кредитних } \\
\text { історій }\end{array}$ & Кількість партнерів & Кількість запитів \\
\hline $\begin{array}{l}\text { Перше Всеукраїнське } \\
\begin{array}{l}\text { бюро кредитних } \\
\text { історій }\end{array}\end{array}$ & 31,5 млн & 368 & 203,3 млн \\
\hline $\begin{array}{l}\text { Українське бюро } \\
\text { кредитних історій }\end{array}$ & 90,8 млн & 4031 & 435,1 млн \\
\hline $\begin{array}{l}\text { Міжнародне бюро } \\
\text { кредитних історій }\end{array}$ & 20,0 млн & 292 & 150,7 млн \\
\hline $\begin{array}{l}\text { Бюро кредитних } \\
\text { історій «Українське } \\
\text { кредитне бюро» }\end{array}$ & 15,5 млн & 81 & 8,4 млн \\
\hline
\end{tabular}

Складено за даними джерел [295, с. 3, с. 4, с. 5]

Як свідчать дані табл. 6.5.1, не всі бюро кредитних історій надають інформацію про свою діяльність щодо переліку та кількості партнерів, кількості кредитних історій тощо. Однак, навіть проаналізувавши показники чотирьох наведених у табл. 6.5.1 бюро кредитних історій, можна відмітити, що хоча кількість банків-партнерів бюро дуже різниться, насправді не можна сказати, що якесь бюро більш поінформоване, а інше - менш. Всі діючі бюро кредитних історій на сьогодні мають свої переваги - це і технологічність сервісу, і повнота інформації, і набір учасників бюро. Однозначного лідера по всіх параметрах на ринку бюро виділити 
складно. Крім цього, цінність бази визначається не тільки кількісним наповненням, а й якісним. Так часто буває, коли позичальник платить одному банку, але при цьому не платить іншому. Відповідно, такий позичальник буде цінним клієнтом для першого і стресовим для іншого банку.

У кожного бюро кредитних історій $є$ партнери серед банків. Якщо фінустанова значиться в списку партнерів, вона може запитувати інформацію про позичальників, а також передає його дані в це бюро. Якщо ж банку в списку партнерів немає, то він, відповідно, не може дізнатися інформацію про позичальника, яка доступна в бюро. Раніше кредитних бюро було більше, i, лавіруючи між різними банками-партнерами, можна було отримати позику і 3 радикально зіпсованою кредитною історією - якщо підібрати банк, який не перетинається через бюро з фінустановою, де недобросовісно погашався кредит.

Сьогодні це вже майже неможливо. На практиці банки, які видають споживчі кредити фізичним особам, $є$ учасниками будь-якого чинного бюро кредитних історій. Отримання кредиту в іншому банку за поганої кредитної історії було можливо, так як деякі банки вважали за краще економити на платних запитах кредитної історії. Але в нинішніх умовах це стає практично неможливим (банки підключаються до більш, ніж одного бюро), так як відомості про позичальника та його кредитну репутацію стають відомі всім учасникам бюро.

Звичайно банківську діяльність не можливо уявити без ризику, оскільки ризик $є$ складовою частиною функціонування банківських установ. Зважаючи на те, що кредити є найбільш прибутковими та найбільш масштабними банківськими активами (питома вага кредитів, наданих банками України у загальній величині їх активів становила у 2018 р. - 61,69\%, у 2019 р. - 55,39\% та у 2020 р. - 47,58\%), то логічно припустити, що найвагоміше значення в системі банківських ризиків належить саме кредитному ризику [299, с. 7]. Аналіз тенденцій кредитування в Україні (табл. 6.6.2) свідчить про те, що:

- за 2018-2020 роки обсяг кредитного портфеля банків України щороку зменшувався (у 2019 р. порівняно із 2018 р. обсяг кредитів зменшився на 95963 млн 
грн, тобто на 8,04\%, а у 2020 р. порівняно із 2019 р. зменшення склало 48016 млн грн, тобто 4,37\%);

- обсяг наданих кредитів корпоративному сектору також щороку зменшувався (у 2019 р. порівняно із 2018 р. обсяг кредитів зменшився на 112342 млн грн, тобто на 11,71\%, а у 2020 р. порівняно із 2019 р. зменшення склало 51854 млн грн, тобто 6,12\%);

- обсяг наданих кредитів фізичним особам у 2019 р. порівняно із 2018 р. зріс на 12050 млн грн, тобто на 5,96\%, а у 2020 р. порівняно із 2019 р. відзначається його зменшення на 100409 млн грн, тобто на 18,92\%;

- обсяг непрацюючих кредитів значно скоротився за 2018-2020 роки ( у 2019 р. порівняно із 2018 р. він зменшився на 99987 млн грн, тобто на 15,85\%, а у 2020 р. порівняно із 2019 р. зменшення склало 100409 млн грн, тобто 18,92\%);

- обсяг сформованих резервів під кредитні ризики у 2019 р. порівняно із 2018 р. зменшився на 75184,5 млн грн, тобто на 13,76\%, а у 2020 р. порівняно із 2019 р. відзначається подальше його зменшення на 106553,1 млн грн, тобто на 22,61\%, що свідчить про покращення стану кредитного портфеля банків України.

Таблиця 6.5.2.

Аналіз динаміки обсягів кредитного портфеля, проблемної заборгованості та сформованих резервів під кредитні ризики банків України за 2018-2020 роки У мільйонах гривень

\begin{tabular}{|l|l|l|l|l|l|}
\hline Роки & $\begin{array}{l}\text { Обсяг } \\
\text { кредитного } \\
\text { портфеля } \\
\text { банків }\end{array}$ & $\begin{array}{l}\text { Обсяг наданих кредитів } \\
\text { у сектору }\end{array}$ & $\begin{array}{l}\text { Обсяг } \\
\text { непрацюючих } \\
\text { кредитів }\end{array}$ & $\begin{array}{l}\text { Обсяг } \\
\text { сформованих } \\
\text { резервів під } \\
\text { кредитні } \\
\text { ризики }\end{array}$ \\
\hline 2018 р. & 1193558 & 959601 & 202202 & 630767 & 546453,1 \\
\hline 2019 р. & 1097595 & 847259 & 214252 & 530780 & 471268,6 \\
\hline Відхилення & & & & & \\
\hline абсолютне & -95963 & -112342 & +12050 & -99987 & $-75184,5$ \\
\hline Відносне, \% & $-8,04$ & $-11,71$ & $+5,96$ & $-15,85$ & $-13,76$ \\
\hline $\begin{array}{l}\text { Темп } \\
\text { приросту, \% }\end{array}$ & 91,96 & 88,29 & 105,96 & 84,15 & 86,24 \\
\hline 2020 р. & 1049579 & 795405 & 208383 & 430371 & 364715,5 \\
\hline Відхилення & & & & & $-106553,1$ \\
\hline абсолютне & -48016 & -51854 & -5869 & -100409 & $-22,61$ \\
\hline Відносне, \% & $-4,37$ & $-6,12$ & $-2,74$ & $-18,92$ & 77,39 \\
\hline $\begin{array}{l}\text { Темп } \\
\text { приросту, \% }\end{array}$ & 95,63 & 93,88 & 97,26 & 81,08 & \\
\hline
\end{tabular}

Складено за даними джерела [299, с. 7] 
Варто зауважити, що за період, який аналізується, частка непрацюючих кредитів у загальному обсязі наданих кредитів банками України з року в рік зменшується (у на 01.01.2019 р. вона становила 52,85\%; на 01.01.2020 р. - 48,36\%; на 01.01 .2021 p. - 41,0\%). Така позитивна динаміка зменшення частки непрацюючих кредитів спостерігається і за кредитами наданими корпоративному сектору економіки, і наданими кредитами фізичним особам (в т.ч. і фізичним особам-підприємцям), про що свідчать дані рис. 6.5.1.

Однак, варто зазначити, що частка непрацюючих кредитів залишається досить значною, що обумовлено дією багатьох чинників, серед яких суттєве місце займає недостатність інформації про кредитну історію позичальників, наявний стан виконання позичальниками заборгованості перед іншими кредиторами та рівень кредитного навантаження на них на момент отримання кредиту у певного банку.

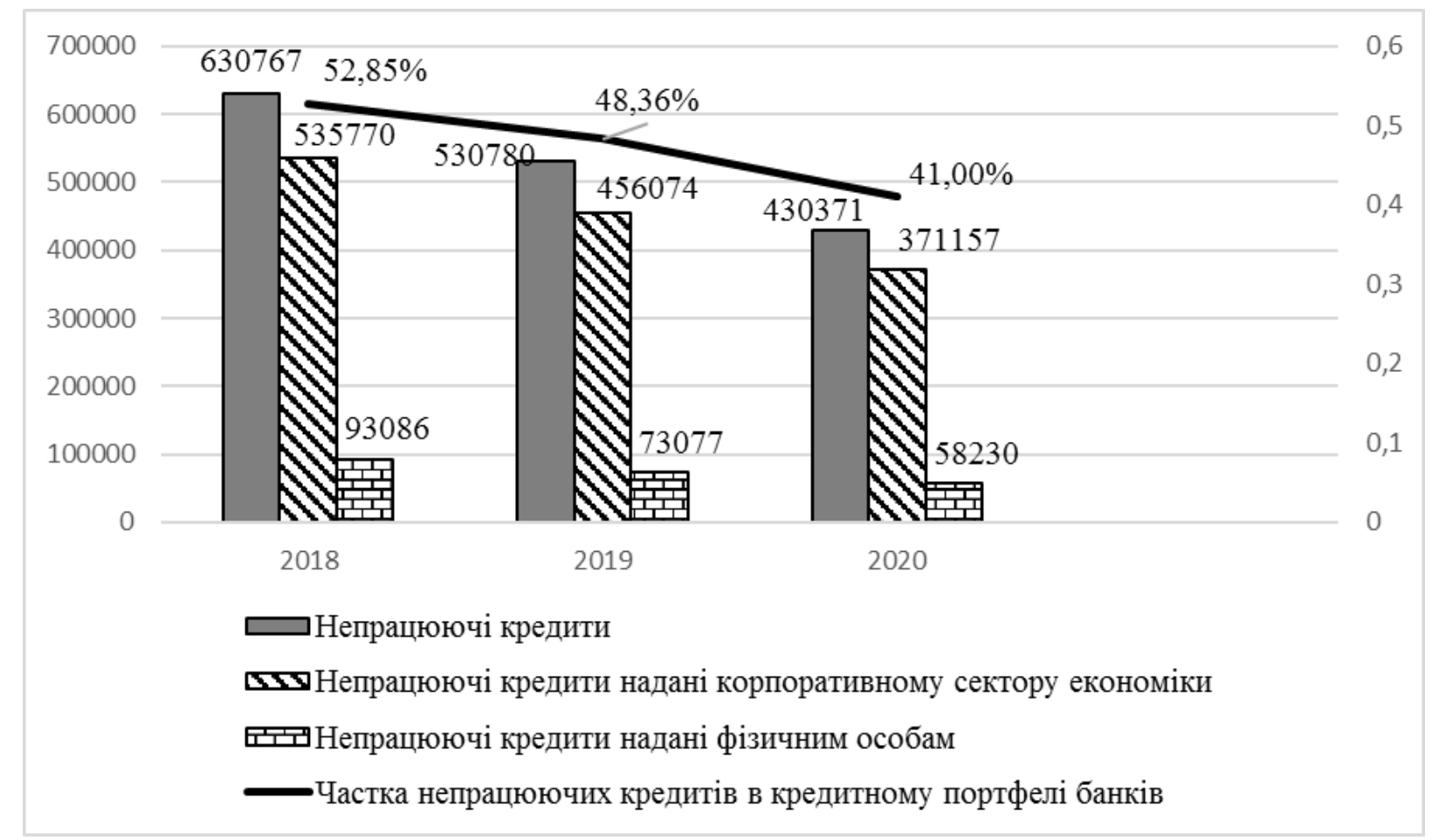

Рис. 6.5.1. Динаміка непрацюючих кредитів наданих банками України та їх частки в їх кредитному портфелі у 2018-2020 роках

Сформовано за даними джерела [299]

Адже банк бачить тільки ту інформацію, яку їм надає сам клієнт, або ту, що вже $\epsilon$ у банку, якщо цей клієнт отримував кредит у цьому банку раніше. 
Проте, на момент звертання до банку за позикою клієнт уже може мати кредити в іншому(их) банку(ах), і невідомо, як він виконує свої боргові зобов'язання за отриманим(и) кредитом(ами), чи платить взагалі і чи буде він погашати новий кредит сумлінно.

Так, наразі, фізичні особи мають можливість одночасно брати кредити в різних банках та кредитних спілках, користуватися кредитними картками, купувати товари з розстрочкою платежу, а банки не мають можливості оцінити та проаналізувати всю заборгованість позичальників, тому позбавлені можливості достовірно оцінити їх платоспроможність, в наслідок чого зростає ризик неповернення кредитів. А відтак, неповернення кредитів як фізичними, так і юридичними особами є одною $з$ основних проблем подальшого розвитку кредитної діяльності банків і посилення їх кредитної підтримки розвитку реального сектору економіки України вирішення важливих соціальних завдань суспільства.

Слід мати на увазі, що за браком достовірної, повної і прозорої інформації про позичальника банки змушені встановлювати однаково високі ставки відсотків за кредитами для всіх позичальників, а відтак сумлінні позичальники змушені платити підвищену надбавку банку за ризик. Тобто, за недобросовісних позичальників розраховуються сумлінні позичальники. Для банків це також не вигідно, оскільки висока вартість кредитів обмежує доступ до них потенційних споживачів банківських кредитів, в наслідок чого скорочуються обороти за кредитами, доходи і прибутки від кредитної діяльності банківських установ. При цьому втрачається певна частка клієнтів. А відтак, в умовах асиметрії інформації про кредитоспроможність і платоспроможність потенційних позичальників стримується темпи зростання обсягів банківського кредитування, що негативно позначається на соціально-економічних показниках країни.

Спектр напрямів діяльності, які здійснюються бюро кредитних історій $\epsilon$ досить варіативним як в окремих бюро, так і в цій складовій інфраструктури функціонуючого кредитного ринку загалом. Першочергово ці напрями поділяються на: 
1) продукти та послуги, що надаються позичальникам;

2) продукти та послуги, що надаються партнерам бюро кредитних історій.

Так, за першим напрямом діяльності бюро кредитних історій щодо надання інформації позичальникам, надають можливість кожній особі перевіряти інформацію щодо наявності в базі даних бюро тї кредитної історії та контролювати достовірність інформації, що міститься в ній. При цьому бюро кредитних історій дбають про фінансову безпеку громадян та забезпечує зручність користування своїми інформаційними сервісами.

За другим напрямом діяльності бюро кредитних історій надають послуги i продукти своїм партнерам, вони пропонують повнофункціональний інструментарій для кредитного ризик-менеджменту. Продукти та послуги бюро можуть бути ефективно використані на всіх етапах кредитного циклу - від аплікаційної стадії до стадії стягнення.

Зазначений перелік продуктів та послуг, що надаються бюро кредитних історій постійно розширюється, а самі види послуг та продуктів удосконалюються під потреби споживачів інформації. Так, сьогодні для банківпартнерів бюро кредитних історій вкрай важливим $є$ питання ймовірності дефолту позичальника. Така послуга, яка має назву «Кредитний бал», сьогодні надається лише одним бюро кредитних історій - Українським бюро кредитних історій. Завдяки цій послузі банки можуть: швидко отримувати уявлення про потенційного позичальника - фізичну особу, підприємця, юридичну особу; поліпшити якість кредитів, що видаються; підтримувати обраний рівень якості свого кредитного портфеля; співпрацювати тільки з перевіреними та надійними партнерами та клієнтами. 